\title{
Pembelajaran daring pada masa pandemi COVID-19: Bagaimana dukungan peran orang tua?
}

\author{
Karolus Suban Waikelak*, Achmad Fakhruddin Arrozy, Lisa Rahmani \\ Universitas Negeri Malang, Jl. Semarang No. 5 Malang, Jawa Timur, Indonesia \\ *Penulis korespondensi, Surel: carloswaichilla@gmail.com
}

Paper received: 3-3-2021; revised: 24-3-2021; accepted: 28-3-2021

\begin{abstract}
Abstrak
Dunia dilanda pandemi Covid-19 yang membawa pengaruh dalam bidang-bidang kehidupan manusia. Dalam bidang pendidikan, proses pembelajaran secara tatap muka berubah menjadi pembelajaran daring. Ada tantangan tersendiri yang dihadapi pihak sekolah dan orang tua dengan pelaksanaan pembelajaran daring. Secara khusus sinergi orang tua dalam mensukseskan pembelajaran daring diperlukan. Peran orang tua merupakan hal yang penting terutama ketika proses pembelajaran daring berlangsung. Siswa yang biasa belajar di sekolah beralih dengan mengikuti pembelajaran dari rumah, di mana akan bersama dengan orang tua. Guru hanya berinteraksi melalui media yang digunakan, baik secara sinkron maupun asinkron. Peran orang tua yang lebih dekat dengan anak dapat membantu anak untuk belajar. Dalam penelitian ini menggunakan kajian pustaka, dengan mengkaji literatur-literatur ilmiah. Hasil kajian menggambarkan bahwa orang tua memiliki peran penting dalam proses pembelajaran terutama pada masa pandemi Covid-19. Pada umumnya orang tua memiliki peran yang sama, tetapi perlu menyesuaikan dengan jenjang pendidikan yang ditempuh anak, agar peran orang tua dalam mendukung anak dapat mencapai tujuan dan proses pembelajaran yang dilakukan secara daring dapat tercapai dengan baik.
\end{abstract}

Kata kunci: pembelajaran daring; pandemi covid-19; peran orang tua

\section{Pendahuluan}

Dunia mengalami situasi sulit sejak akhir tahun 2019. Situasi ini berlanjut sampai dengan saat ini pada pertengahan Maret 2021. Pada tanggal 18 Maret 2021, jumlah negara yang terpapar Covid-19 berdasarkan laporan dari Organisasi Kesehatan Dunia pada website sebanyak 223 negara, wilayah atau teritori dengan kasus Covid-19 (WHO, 2021). Pandemi telah berlangsung kurang lebih satu tahun yang dimulai pada Maret 2020 sampai dengan sekarang per Maret 2021.

Kondisi pandemi yang melanda dunia dan secara khusus di Indonesia, maka pihak pemerintah Indonesia sebagai pihak berwenang untuk menetapkan kebijakan, langkah, dan strategi dalam menghadapi pandemi Covid-19. Penetapan untuk mencegah menyebarnya virus corona. Salah satu langkah yang diambil dalam bidang pendidikan yaitu berkaitan dengan proses pelaksanaan pembelajaran yang dapat dilakukan dari rumah atau study from home yang diberlakukan pada semua jenjang, yaitu jenjang pendidikan Pendidikan Anak Usia Dini/Taman Kanak-Kanak (PAUD/TK), Sekolah Dasar (SD), Sekolah Menengah Pertama (SMP), Sekolah Menengah Atas (SMA), dan pada jenjang pendidikan tinggi. Anjuran dari pemerintah di tengah situasi agar pembelajaran tetap berjalan. Cara yang dapat ditempuh sesuai dengan kebijakan pemerintah yaitu pembelajaran dapat dilaksanakan dengan cara daring atau pembelajaran secara online bagi siswa dari rumah mereka masing-masing. Data perkembangan penyebaran menunjukkan wilayah penyebaran Covid-19 semakin banyak dan luas, sehingga pembelajaran dari rumah masih tetap berjalan sampai dengan sekarang (Irawati \& Santaria, 2020).

This work is licensed under a Creative Commons Attribution-ShareAlike 4.0 International License. 
Salah satu hal penting dalam kehidupan manusia adalah meraih pendidikan. Setiap warga negara Indonesia tanpa memandang perbedaan dari segi apapun, pendidikan adalah hak untuk semua orang yang dijamin oleh negara. Pendidikan yang diperoleh memiliki taraf perkembangan, di mana selama manusia masih hidup, pendidikan tidak lepas dalam proses hidup manusia itu sendiri. Pendidikan sepanjang hayat (life long education) bagi setiap orang tanpa dibatasi oleh suatu perbedaan. Dalam pandangan umum, pendidikan memiliki arti sebagai suatu proses yang dilalui bagi setiap individu untuk mengembangkan diri sesuai dengan kemampuannya dalam seluruh proses kehidupan yang dialami agar dapat memperoleh hidup serta kelangsungan kehidupan dapat terus berjalan. Dapat dikatakan bahwa sangat penting bagi seseorang yang dipandang sebagai orang terdidik yang dicapai memiliki pendidikan yang ditempuhnya. Dengan demikian melalui pendidikan seseorang dapat mengekspresikan diri melalui suatu karya yang bermanfaat dan berguna dalam kehidupan bangsa dan negara. (Sari et al., 2020). Pendidikan tetap dijalankan pada zaman ini dengan kemajuan dalam bidang teknologi. Program pendidikan seperti pembelajaran dapat dilaksanakan dengan memanfaatkan sumber daya yang dapat membantu proses pelaksanaannya di tengah pandemi Covid-19.

Kebijakan penutupan sekolah khususnya di Indonesia dilandasi oleh keputusan dari kementerian yang terkait, yaitu Kementerian Pendidikan dan Kebudayaan bersama beberapa kementerian yang lain, yang tertuang dalam Surat Keputusan Bersama (SKB) yang dimulai sejak Maret 2020 dan masih berlanjut sampai dengan sekarang per Maret 2021. Penutupan sekolah ini akan terus berlanjut pada saat situasi pandemi Covid-19 masih terjadi. Pembelajaran tatap muka belum diketahui dengan pasti kapan dilakukan, sehingga pembelajaran daring masih tetap berjalan sebelum adanya keputusan dari pihak berwenang menyesuaikan situasi dan kondisi bebas serta aman dari Covid-19.

Pada saat siswa berada di rumah mengikuti pembelajaran seperti ketika pandemi Covid$19 \mathrm{ini}$, selain dibutuhkan keterampilan untuk mengasuh dengan baik oleh orang tua, tetapi juga yang dibutuhkan adalah memiliki pengetahuan yang baik. Orang tua akan memantau perilaku anak dan kinerja anak ketika di rumah, serta usaha orang tua untuk kebutuhan pendidikan anak harus dapat dipenuhi secara efektif (Abuhammad, 2020). Orang tua dapat secara langsung bersama anak dalam pembelajaran seperti pada jam efektif tatap muka di sekolah. Tingkah laku, tanggapan, dan pemahaman anak dalam belajar dapat dipantau, sehingga tanggung jawab orang tua dapat mendukung, memotivasi, dan membantu anak untuk belajar secara efektif dan efisien.

Pembelajaran secara online atau disebut juga e-learning dapat ditinjau dari dasarnya adalah pembelajaran yang dilaksanakan secara jarak jauh yang dapat diartikan sebagai pembelajaran jarak jauh (Belawati, 2020). Di dalam pembelajaran daring yang dilaksanakan, perlu diperhatikan aspek-aspek yang terkait, seperti guru, siswa, dan teknologi, serta aspek peran dari orang tua itu sendiri. Peran orang tua siswa dalam pembelajaran menjadi satu aspek penting karena pembelajaran daring dapat ditunjang sehingga berjalan dengan baik sesuai harapan dari pihak sekolah dan orang tua (Andini, Y. T, \& Widayanti, 2020).

Tanggung jawab orang tua dalam pendidikan bagi anak dipandang sangat penting, sehingga di mulai dari rumah, peran pendidik dari orang tua bagi anak adalah yang pertama dan utama diterima anak (Kawuryan, 2016). Kedudukan utama dimiliki oleh orang tua, di mana dalam kehidupan berkeluarga orang tua sebagai pendidik pertama. Hal-hal yang 
berkaitan dengan pengetahuan bagi anak baik khusus dan umum, orang tua dapat memberikan perhatian secara keseluruhan (Astuti; Rivaie; \& Ibrahim, 2013). Sejak anak dilahirkan sampai bertumbuh menjadi pribadi dewasa, tanggung jawab bagi orang tua dapat berupa pengasuhan bagi anak, mendidik, serta membimbing anak tetap diperhatikan dan dilakukan. Dalam situasi pandemi Covid-19 dialami bersama ini, yang menyebabkan dilakukan pembelajaran secara daring, pada tempat pertama dibutuhkan peran yang berasal orang tua peran orang tua sebagai tempat pertama bagi anak memperoleh pendidikan untuk diterapkan. Orang tua dapat mengalami tanggung jawab yang utuh bagi kehidupan anak (Rahmawati, 2021).

Dalam mewujudkan dan mendukung kemandirian belajar siswa di rumah pada waktu menghadapi masa pandemi covid-19, dalam menjalin komunikasi yang baik terjadi antara pihak sekolah yaitu guru dan orang tua merupakan hal penting yang perlu diperhatikan oleh kedua belah pihak yang dapat mendukung kelancaran proses pembelajaran berlangsung sesuai dengan harapan (Herliandry et al., 2020). Perlu dorongan dan bantuan dari orang tua untuk memberikan rasa aman dan menghindari rasa takut dalam diri anak. Sumber informasi yang benar dan akurat dapat disampaikan kepada anak dan contoh hidup sehat dapat dipraktikkan oleh orang tua agar anak dapat mengikuti. Dalam pembelajaran di rumah bisa terjadi ada masalah yang dihadapi seperti rasa cemas anak yang menyebabkan kurang konsentrasi dan bisa tidur saat pembelajaran, tetapi melalui dukungan yang diberikan dapat teratasi hambatan yang dihadapi (Morgan, 2020).

Proses pelaksanaan pembelajaran melibatkan pihak-pihak yang terkait, di antaranya adalah keterlibatan guru dan murid sebagai pihak yang terlibat langsung sehingga pembelajaran dapat berjalan. Namun dibutuhkan juga dukungan dari orang tua siswa sehingga dapat membantu terlaksananya pembelajaran apabila dilakukan pembelajaran online. Untuk orang tua dengan anak pada usia sekolah tingkat tertentu, memiliki peran sesuai dengan tingkat pendidikan anak tersebut. Pada umumnya peran yang sama dilakukan oleh orang tua dalam memberikan dukungan pembelajaran terhadap anak.

Dari pemaparan-pemaparan yang dikemukakan di atas, pembahasan yang dikaji penulis adalah tentang peran orang tua dalam memberikan dukungan proses pelaksanaan pembelajaran daring selama masa pandemi Covid-19. Bagaimana dukungan peran orang tua secara langsung diberikan kepada anak sehingga pembelajaran daring yang efektif dalam pelaksanaannya dapat terwujud dan berjalan dengan efisien? Uraian peneliti dalam artikel ini berkaitan dengan peran orang tua dalam mensukseskan pembelajaran daring yang telah dilaksanakan sejak awal pandemi Covid-19 yang melanda dunia sampai sekarang ini.

\section{Metode}

Penelitian yang dilakukan dalam penulisan artikel ini adalah jenis penelitian studi pustaka. Peneliti menggunakan data-data sekunder sebagai acuan penyusunan artikel ini yang berhubungan dengan pembelajaran daring pada masa pandemi Covid-19 yang mengkaji dari segi peran orang tua dalam pembelajaran daring yang dijalankan anak. Berdasarkan teori-teori dan temuan-temuan yang telah dipublikasi. Sumber data yang digunakan adalah jurnal ilmiah dan sumber lain yang relevan dan memiliki tema sesuai dengan yang penulis bahas dalam artikel ini. 


\section{Hasil dan Pembahasan}

\subsection{Hasil}

Himbauan dari pemerintah Indonesia untuk masyarakat saat pandemi Covid-19 adalah penerapan sosial distancing, lock down, dan taat protokol kesehatan. Tujuannya untuk mencegah penularan virus corona yang telah pandemi melanda dunia. Dalam pelaksanaan proses pembelajaran, diberlakukan belajar dari rumah (study from home) atau sekolah dari rumah (school from home) sebagaimana masyarakat pada umumnya dihimbau untuk melakukan pekerjaan dari rumah (work from home). Melakukan sesuatu kegiatan seperti pekerjaan kantor dan belajar di kelas dari rumah akan berpengaruh pada aktivitas bersama untuk membatasi gerak manusia. Terhindar dari kumpul bersama dalam jumlah banyak orang. Kegiatan sosial masyarakat di luar rumah dibatasi. Untuk kegiatan belajar mengajar, pemerintah menetapkan untuk dilaksanakan juga dari rumah. Proses pelaksanaan pembelajaran antara guru dan siswa dapat melalui media. Guru mengajar dan menyampaikan materi dengan menggunakan hp yang terkoneksi dengan internet. Oleh karena itu, cara atau strategi yang tepat dari orang tua dapat diterapkan dalam mendidik anak dalam situasi yang dihadapi bersama sekarang ini. Segala hal yang dipelajari anak di rumah bersama orang tua dapat dilihat untuk sementara waktu peran guru yang biasa dilakukan di sekolah diganti oleh orang tua yang dapat dimaknai sebagai proses belajar dari rumah (Ahsani, 2020).

Dalam mendukung kegiatan pembelajaran daring anak di rumah, sebagai orang tua sebagian besarnya melibatkan diri. Namun ada juga orang tua yang terkendala dan kesulitan seperti pembagian waktu, perhatian dan penjelasan materi pelajaran kepada anak (Novianti \& Garzia, 2020). Orang tua dibutuhkan keterlibatannya dalam pelaksanaan pembelajaran daring, ketika anak berada di rumah dan mengikuti pembelajaran. Orang tua secara langsung bersama anak dalam belajar, sedangkan hubungan guru dan siswa hanya terbatas melalui media yang digunakan. Berbagi waktu antara pekerjaan rumah dan mendampingi anak menjadi tantangan tersendiri, memberi perhatian kepada anak dan juga bisa menjelaskan materi pelajaran apabila anak mengalami kesulitan.

Melalui pembelajaran daring yang dilakukan, beberapa hal dapat terjalin antara orang tua dengan anak mereka. Meningkatnya hubungan sebagai orang tua dan anak, perkembangan anak dalam kaitan dengan kemampuan dan belajar anak secara langsung dapat dilihat oleh orang tua (Cahyati \& Kusumah, 2020). Peran orang tua dalam mengganti guru seperti ketika belajar tatap muka, dukungan berupa menyiapkan fasilitas yang diperlukan, dan memotivasi anak dalam belajar (Wijayanti \& Fauziah, 2020). Beberapa peran orang tua yang lain yang ditemukan dalam pembelajaran daring, yaitu ikut serta dalam kegiatan pembelajaran anak, mempersiapkan bagi anak kebutuhan yang diperlukan dalam pembelajaran, memberi semangat atau motivasi untuk anak, menyesuaikan dengan waktu kerja ketika mengajar anak, mempersiapkan fasilitas yang dibutuhkan anak, memberikan bimbingan belajar kepada anak, membantu untuk menjelaskan hal-hal spiritual, dan memberikan apresiasi kepada anak dalam belajar (Yulianingsih et al., 2020).

Langkah memutuskan penyebaran Covid-19 untuk para siswa dapat ditempuh dengan cara belajar dari rumah untuk semua siswa. Lembaga pendidikan yang menyelenggarakan pendidikan secara formal dapat mengatasi dengan terhindar dari keramaian bila pembelajaran tidak dilaksanakan dalam kelas. Penerapan sistem belajar yang dikenal dengan school from 
home, pada segi orang tua tidak melepaskan perannya, tetapi peran penting orang tua masih tetap dibutuhkan dalam proses belajar untuk siswa dalam sistem daring atau online seperti yang dihadapi sekarang ini. Sistem belajar di rumah ini menjadikan orang tua berperan sebagai pendidik di rumah sebagai ganti peran pendidik bagi guru ketika pembelajaran di sekolah (Ahsani, 2020).

Secara umum peran orang tua dapat ditunjukkan sebagai pendidik, pengembang, penjaga, pembimbing, dan pengawas bagi anak dan secara khusus peran orang tua yang dapat ditampilkan seperti dalam penerapan untuk bagian kebersihan dan kesehatan dengan anak dijaga serta dipastikan melakukan, anak didampingi untuk pengerjaan tugas belajar yang diberikan guru, bersama melakukan kegiatan ketika di rumah, penciptaan lingkungan yang aman dan tertib bagi anak, intensitas relasi komunikasi yang terjalin sebagai anak dan orang tua, anak diajak bermain bersama, orang tua menempatkan diri sebagai panutan atau teladan (role model) untuk anak, menerapkan sistem pengawasan bagi anggota keluarga, memenuhi kebutuhan hidup dalam keluarga, serta anak dibimbing dan dimotivasi, pemberian edukasi yang penting, menjaga hidup rohani (agama) anak, serta melakukan dan menerapkan variasi serta inovasi dalam kegiatan belajar ana di rumah (Kurniati et al., 2020).

\subsection{Pembahasan}

Pernyataan resmi dari Organisasi Kesehatan Dunia mengenai pandemi Covid-19 dapat menjadi ancaman bagi manusia dewasa ini. Penyebaran yang begitu cepat dan meluas ke daerah-daerah di Indonesia. Keadaan ini dapat menyebabkan secara terpaksa ditutupnya berbagai kegiatan secara global, salah satunya adalah kegiatan dalam pendidikan dengan berpindah pada pembelajaran online. Dunia pendidikan menghadapi suatu krisis yang perlu direspon. Aktivitas pendidikan dalam pembelajaran dari tingkat bawah sampai universitas dapat menjadi sebuah tantangan dan peluang. Kegiatan instruksional bisa berkembang dimana tantangan yang dialami selama pandemi ini dapat dieksplorasi dengan baik dan diubah menjadi sebuah peluang di masa yang akan datang (Adedoyin \& Soykan, 2020). Dapat didefinisikan bahwa pembelajaran online adalah pengalaman pembelajaran dalam mentransfer ilmu pengetahuan dapat berupa video, gambar, audio, perangkat lunak, dan komunikasi teks (Basilaia \& Kvavadze, 2020) dan didukung dengan jaringan internet untuk menghubungkannya (Zhu \& Liu, 2020).

Metode pembelajaran jarak jauh pada saat ini dengan adanya pandemi Covid-19 adalah pembelajaran daring sebagai salah satu pilihan yang populer. Selama masa lockdown covid-19, pembelajaran daring menjadi suatu bentuk terbaik sehingga antara guru dan siswa tetap terlibat dalam pembelajaran dan aman dengan menjaga jarak sosial antara satu dengan yang lain (Jena, 2020). Pembelajaran daring merupakan pembelajaran dengan model interaktif yang menggunakan sambungan internet dan di dalamnya menerapkan Learning Manajemen System (LMS). Sehingga di dalam pembelajaran daring dapat diselenggarakan kelas dengan program yang memiliki jangkauan target kelas yang banyak serta luas untuk semua siswa yang mengikuti (Bilfaqih \& Qomaruddin, 2015).

Penutupan fisik ini menyebabkan pergeseran cepat ke pembelajaran jarak jauh yang menempatkan lebih banyak tanggung jawab untuk belajar pada orang tua dan wali (Garbe et al., 2020). Untuk beberapa siswa dalam pemahaman tentang pembelajaran dalam jaringan adalah suatu hal baru yang dipengaruhi dengan akses dan koneksi jaringan yang belum 
terintegrasi dengan baik. Diperlukan upaya-upaya yang maksimal dan tepat dalam pelaksanaan pembelajaran jarak jauh. Sehingga tujuan pembelajaran yang telah direncanakan tercapai berdasarkan penetapan kurikulum (Kurnianto \& Rahmawati, 2020).

Proses belajar anak-anak dengan jarak jauh (online) dilaksanakan dari rumah masingmasing. Lebih banyak peran dibutuhkan oleh orang tua, di mana situasi ini akan terpolarisasi dari segi beban guru dan sekolah dalam pembelajaran (Saragih \& Hasugian, 2020). Dalam dunia pendidikan bagi lembaga yang menyelenggarakan pendidikan baik diselenggarakan oleh pihak pemerintah maupun pihak swasta, pilihan yang tidak dapat dielakkan adalah pembelajaran daring. Pilihan metode pembelajaran daring ini sebagai suatu solusi mengatasi pandemi Covid-19, sehingga proses pembelajaran dapat dilaksanakan seperti pada situasi normal dengan adanya pembelajaran tatap muka di kelas. Dengan demikian pembelajaran tetap berjalan dengan melibatkan guru untuk tetap mengajar dan siswa masih dapat belajar di rumah ketika pandemi belum berakhir. Ciri khusus atau identik dari pembelajaran daring adalah memanfaatkan perangkat teknologi yang dapat disambungkan dengan internet, sehingga memiliki ketergantungan dengan tersedianya teknologi informasi yang memadai (Asmuni, 2020).

Dampak Covid-19 mengharuskan siswa untuk mengikuti pembelajaran daring atau dalam perkembangan istilah umum disebut pembelajaran jarak jauh dengan pelaksanaan pembelajaran terjadi dari rumah. Dengan pemanfaatan daya internet ketika pembelajaran dilaksanakan, guru dapat menjalin secara virtual komunikasi dengan siswa secara langsung, melalui penggunaan aplikasi yang dapat diinstal pada handphone seperti whatsapp, google meet, quizizz, zoom, live chat, dan aplikasi lainnya yang memanfaatkan adanya internet untuk mengoperasikan aplikasi-aplikasi tersebut. Penggunaan aplikasi ini dapat disesuaikan oleh guru dan siswa sehingga pembelajaran dapat berjalan. Pengembangan pembelajaran yang dilakukan secara daring dapat mencapai tujuan dalam perluasan jangkauan pelayanan pendidikan yang dapat diakses dan tersedia bagi selama masih ada pandemi Covid-19 (Atiqoh, 2020). Pembelajaran daring (dalam jaringan) semakin dikenal dan diterapkan ketika masa pandemi Covid-19. Istilah-istilah lain berhubungan dengan pembelajaran daring yang dapat ditemukan seperti pembelajaran jarak jauh, belajar dari rumah (study from home), dan pembelajaran online. Dalam proses pembelajaran daring, guru dan siswa tidak secara langsung bertemu seperti waktu pembelajaran di kelas, tetapi dengan menggunakan beberapa media yang mendukung interaksi dalam pertemuan yang terkoneksi dengan internet, seperti android $(h p)$, tablet, laptop, dan komputer yang dimiliki dan bisa digunakan. Pembelajaran dapat dilaksanakan secara sinkronus dan asinkronus.

Orang tua dalam melakukan pendampingan terhadap anak dapat meliputi pendampingan dalam perilaku anak, pendampingan terhadap sikap anak, pendampingan tata cara berbicara, pendampingan untuk menjalankan ibadah, dan pendampingan terhadap belajar (Apriliana, 2017). Praktis dalam pelaksanaan pembelajaran daring dari rumah pada masa pandemi Covid-19 secara langsung melibatkan orang tua dalam memberikan dukungan dan fasilitas. Mendampingi anak ketika belajar secara daring dibutuhkan sehingga dengan tujuan pembelajaran yang ditetapkan dan proses pembelajaran yang dilakukan dapat dicapai dengan baik. Pendampingan dari orang tua dapat diterapkan ketika proses pembelajaran daring dilakukan. Mendampingi anak dalam hal berperilaku, bersikap, berbicara, beribadah, dan dalam hal belajar. 
Antara peran guru dan orang tua tidak dapat dibedakan. Kedua bentuk peran yang dijalankan merupakan satu kesatuan yang saling berhubungan. Peran yang dijalankan oleh orang tua di rumah dalam pembelajaran daring merupakan suatu bentuk peran bagi guru di sekolah. Pembelajaran dari rumah yang terjadi membutuhkan peran orang tua yang dapat mengganti peran guru terutama untuk membimbing anak dalam waktu pembelajaran daring berlangsung. Tanggung jawab diberikan kepada orang tua untuk membimbing, mendidik, dan mengasuh anak, agar dapat tercapai tahap-tahap tertentu untuk anak ketika memasuki hidup di tengah masyarakat secara siap dan dewasa (Ruli, 2020). Peran penting keluarga untuk anak dilakukan dengan suatu dorongan dalam penanaman kebiasaan serta tingkah laku, penanaman nilai-nilai yang berhubungan agama dan moral yang dilandasi dengan kebiasaan dalam keluarga serta menyesuaikan usia anak sehingga dapat diterapkan dengan baik (Zahrok \& Suarmini, 2018).

Proses pelaksanaan pembelajaran yang dilakukan secara daring membutuhkan dukungan dan keterlibatan orang tua. Peran orang tua yang dapat dilakukan ketika anak berada di rumah dan mengikuti pembelajaran daring agar proses pembelajaran berjalan dan tujuan pembelajaran dapat dicapai dengan baik, antara lain orang tua dapat membimbing dan mendampingi belajar anak, orang tua berperan menjadi fasilitator, orang tua dapat menjadi motivator, orang tua dapat menjadi pengarah dalam belajar, dan orang tua dapat menjadi teladan bagi anak (Sapardan, 2020; Winingsih, 2020; \& Hidayat, 2020).

\subsubsection{Peran orang tua dalam memberikan bimbingan dan mendampingi belajar anak}

Orang tua membutuhkan waktu ekstra untuk mendampingi anak belajar, di mana orang tua juga menyelesaikan pekerjaan dari kantor atau pekerjaan rutin yang biasa dikerjakan agar semuanya dapat berjalan dengan baik. Orang tua menghadapi tantangan baru dalam mengerjakan tugas-tugas kantor atau pekerjaan rutin rumah lainnya. Maka dalam proses membimbing dan mendampingi yang dilakukan orang tua saat berada di rumah, tidak semua peran guru di sekolah untuk orang tua tidak dapat digantikan seluruhnya. Pendampingan orang tua dapat dilakukan dengan suatu pendekatan yang dapat membantu anak. Pendekatan MIKIR dapat dijadikan sebagai suatu strategi bagi orang tua untuk diterapkan dalam membimbing dan mendampingi anak belajar di rumah (Diana, 2020).

(1) Membuat jadwal dan aturan bersama. Dengan jadwal yang telah dibuat bersama, maka anak diingatkan akan jadwal tersebut. Adanya tanggung jawab bersama dalam keluarga baik untuk anak dan orang tua, agar menjadi tanggung jawab yang dapat dijalani secara bersama-sama. (2) Ide Kegiatan. Memiliki sikap untuk membantu anak, terutama ketika melihat anak mengalami kesulitan atau kebingungan menyusun kegiatan yang akan dilakukan pada hari tersebut. (3) Komunikasi yang positif. Dukung anak dalam melakukan suatu kegiatan. Sikap positif dapat menjalin komunikasi yang baik, seperti bertanya tentang sesuatu secara positif. (4) Ingat tentang waktu serta berintrospeksi diri. Dapat membagi waktu dengan baik untuk suatu kegiatan sehingga menjadi bermakna. Setiap kegiatan perlu diingatkan untuk mengikuti waktu yang ditetapkan sesuai dengan pembagiannya. Sebagai orang, perlu introspeksi dalam diri sendiri, bahwa tidak semua hal dapat diketahui dan dipahami atau orang tua bukanlah orang yang tahu segalanya. (5) Relasi dan Refleksi. Membangun relasi dengan siapapun dalam keluarga dan secara luas di lingkungan merupakan sesuatu yang baik. Orang tua perlu juga merefleksi diri mengenai makna dari apa yang telah dikerjakan dalam hidup 
bersama, baik kegiatan yang formal maupun informal melalui aktivitas yang telah dikerjakan dan pengalaman yang dialami bersama atau cara-cara lainnya sebagai jalan untuk merefleksikan diri.

\subsubsection{Peran orang tua sebagai fasilitator}

Kaitan dalam peran ini adalah fasilitas yang disediakan. Fasilitas bisa berupa suatu barang yang dibutuhkan maupun diri orang tua itu sendiri. Sarana prasarana yang dibutuhkan anak dalam pembelajaran online. Sebuah prasyarat terlaksananya pembelajaran daring adalah tersedianya fasilitas yang dibutuhkan, tetapi perlu disesuaikan dengan kemampuan yang dimiliki orang tua untuk menyiapkan sarana prasarana sebagai pendukung. Dengan demikian, orang tua menjadi fasilitator yang baik

\subsubsection{Peran orang tua sebagai motivator}

Motivasi dari orang tua terhadap anak dalam pembelajaran daring juga dibutuhkan anak. Dengan dukungan motivasi dapat meningkatkan semangat. Anak akan menjadi rajin, semangat, dan prestasi anak bisa meningkat. Motivasi-motivasi yang diberikan bisa berupa kata-kata pujian dan nasihat, dan bisa berupa menambah barang kebutuhan sekolah. Tidak semua anak dapat memotivasi diri, tetapi membutuh motivasi dari luar diri. Motivasi orang terdekat seperti dari orang tua dapat menjadi sebuah dorongan untuk anak untuk berbuat sesuatu. Dengan menerapkan pola asuh yang baik, membawa dampak tingginya motivasi dalam belajar sehingga fasilitas dapat dimanfaatkan dengan maksimal. Motivasi dalam belajar bagi siswa dapat dipengaruhi oleh lingkungan tempat belajar anak dan pola asuh orang tua sehingga dapat menjadi penentu kualitas dalam belajar (Harianti \& Amin, 2016). Wujud dari motivasi yaitu adanya semangat serta keinginan dalam diri untuk mau belajar. Motivasi merupakan hal penting dalam kegiatan belajar, sehingga dengan motivasi tersebut anak akan berhasil dalam belajarnya.

\subsubsection{Peran orang tua sebagai pengarah}

Mengarahkan anak untuk masa depannya adalah sebagai visi untuk anak dari orang tua. Menjadi pengarah yang baik tidak bersikap otoriter, tetapi mendengar juga dari kemauan dan keinginan anak sendiri. Mengarahkan anak dapat menyesuaikan bakat dan minat anak dan tidak terkesan memaksa. Menyesuiakan juga dengan kemampuan anak agar tidak gagal pada kemudian hari atau gagal di tengah jalan.

\subsubsection{Peran orang tua sebagai teladan}

Waktu anak di rumah bersama orang tua akan memiliki pengaruh bagi anak. Dengan jangkauan indra yang dapat secara langsung dilihat, didengar, dan dirasa dapat berpengaruh kepada anak. Dilihat oleh anak sesuatu yang dikerjakan orang dan didengar oleh anak yang diucapkan orang tua, begitu juga sesuatu yang dialami dan dirasakan yang berasal dari orang tua. Kesesuaian antara kata dan tindakan dapat menjadi ukuran bagi anak. Sosok orang sebagai teladan atau panutan bagi anak perlu disadari dan dikembangkan dalam kehidupan bersama. Kesesuaian kata dan tindakan orang tua perlu diperhatikan.

Sosok orang tua diperlukan anak dalam menjalin intensitas lewat pertemuan antara anak dan orang tua, sehingga koordinasi pembelajaran anak oleh orang tua kepada guru dapat 
memberi gambaran perkembangan pembelajaran yang diikuti oleh anak saat belajar dari rumah. Pengembangan sumber daya yang profesional merupakan dukungan orang tua bagi siswa, dapat membimbing mereka dalam belajar sesuai dengan konten, mengembangkan keterampilan dalam pengajaran jarak jauh, atau secara umum dapat dipahami sebagai peningkatan kapasitas yang berguna untuk mendukung siswa sehingga dapat belajar lebih mandiri (Reimers et al., 2020).

\section{Simpulan}

Dalam pelaksanaan pembelajaran daring selama pandemi Covid-19, peran bagi orang tua di rumah untuk mendukung proses pembelajaran agar dapat berjalan dengan baik, seperti peran sebagai pendidik, pembimbing, motivator, fasilitator, pendamping, pengawas, dan pengontrol (Khasanah, 2021; Chusna \& Utami, 2020). Dari peran-peran ini dapat dijalankan oleh orang tua dengan anak yang sedang menjalani pendidikan pada jalur formal yaitu SD, SMP, dan SMA dan jalur nonformal seperti PAUD/TK. Dengan menyesuaikan tingkat pendidikan anak, kemampuan anak, sikap dan perilaku anak dalam mengikuti pembelajaran, orang tua dapat berperan sesuai dengan situasi yang dialami bersama anak. Peran tersebut dapat dijalankan ketika pembelajaran daring sedang dilaksanakan bersama guru lewat media yang digunakan maupun setelah pembelajaran selesai. Peran orang tua yang memiliki anak pada usia PAUD/TK dan SD akan membutuhkan lebih banyak peran, bila dibandingkan peran bagi orang tua dengan anak pada usia dan jenjang pendidikan di tingkat menengah yaitu SMP dan SMA. Dalam proses penerapannya, peran orang tua untuk setiap jenjang akan berbeda. Bentuk dukungan orang tua dengan peran yang tepat dapat membantu anak sehingga dapat memberikan andil yang berguna dalam pembelajaran yang diikuti anak dari rumah, dalam aspek pengetahuan, afeksi, dan psikomotorik di samping orang tua mengerjakan pekerjaan rumah mereka. Dengan keterlibatan orang tua dalam pembelajaran anak, dapat membantu dan mendukung anak untuk mencapai pembelajaran yang maksimal.

\section{Daftar Rujukan}

Abuhammad, S. (2020). Barriers to distance learning during the COVID-19 outbreak: A qualitative review from parents' perspective. Heliyon, 6(11), e05482. https://doi.org/10.1016/j.heliyon.2020.e05482

Adedoyin, O. B., \& Soykan, E. (2020). Covid-19 pandemic and online learning: the challenges and opportunities. Interactive Learning Environments, O(0), 1-13. https://doi.org/10.1080/10494820.2020.1813180

Ahsani, E. L. F. (2020). Strategi Orang Tua dalam Mengajar dan Mendidik Anak dalam Pembelajaran At The Home Masa Pandemi Covid-19. Jurnal Al_Athfal, 3(1), 37-46.

Andini, Y. T., \& Widayanti, M. D. (2020). Pelaksanaan Pembelajaran Daring Pada Masa Pandemi Covid-19 Di TK Bias Yogyakarta. Tarbiyatuna: Kajian Pendidikan Islam, 4(2), 206-216.

Apriliana, E. S. (2017). Pendampingan Anak dalam Keluarga di TK Pertiwi Kebasen Kabupaten Banyumas. Jurnal Elektronik Mahasiswa Pend. Luar Sekolah - S1, 287-298.

Asmuni, A. (2020). Problematika Pembelajaran Daring di Masa Pandemi Covid-19 dan Solusi Pemecahannya. Jurnal Paedagogy, 7(4), 281. https://doi.org/10.33394/jp.v7i4.2941

Astuti, Dewi; Rivaie, Wanto; \& Ibrahim, Y. (2013). Analisis Peran Orang Tua dalam Meningkatkan Hasil Belajar Siswa Kelas X SMK Muhammadyah Pontianak. Journal Untan, 4(1), 64-71. http://jurnal.untan.ac.id/index.php/JPSH/article/view/22027/17653

Atiqoh, L. N. (2020). Respon Orang Tua Terhadap Pembelajaran Daring Pada Masa Pandemi Covid-19. Thufuli : Jurnal Ilmiah Pendidikan Islam Anak Usia Dini, 2(1), 45. https://doi.org/10.33474/thufuli.v2i1.6925

Basilaia, G., \& Kvavadze, D. (2020). Transition to Online Education in Schools during a SARS-CoV-2 Coronavirus (COVID-19) Pandemic in Georgia. Pedagogical Research, 5(4). https://doi.org/10.29333/pr/7937

Belawati, T. (2020). Pembelajaran Online (Edisi Kedua). Universitas Terbuka.

Bilfaqih, Y. \& Qomaruddin, M. N. (2015). Esensi Pengembangan Pembelajaran Daring. Deepublish. 
Cahyati, N., \& Kusumah, R. (2020). Peran Orang Tua Dalam Menerapkan Pembelajaran Di Rumah Saat Pandemi Covid 19. Jurnal Golden Age, 4(01), 4-6. https://doi.org/10.29408/jga.v4i01.2203

Chusna, P. A., \& Utami, A. D. M. (2020). Dampak Pandemi Covid-19 Terhadap Peran Orang Tua Dan Guru Dalam Meningkatkan Kualitas Pembelajaran Daring Anak Usia Sekolah Dasar. PREMIERE : Journal of Islamic Elementary Education, 2(1), 11-30. https://doi.org/10.51675/jp.v2i1.84

Diana, R. (2020). Peran Orang tua Dalam Pendidikan Anak di Era Pandemi Covid-19.

Garbe, A., ogurlu, U., Logan, N., \& Cook, P. (2020). Parents' Experiences with Remote Education during COVID19 School Closures. American Journal of Qualitative Research, 4(3), 45-65. https://doi.org/10.29333/ajqr/8471

Harianti, Rini \& Amin, S. (2016). Pola Asuh Orangtua Dan Lingkungan Pembelajaran Terhadap Motivasi Belajar Siswa. Curricula, 2(2), 20-30. https://doi.org/10.22216/jcc.v2i2.983

Herliandry, L. D., Nurhasanah, Suban, M. E., \& Heru, K. (2020). Pandemic learning during the Covid-19. Jurnal Teknologi Pendidikan, 22(1), 65-70. http://journal.unj.ac.id/unj/index.php/jtp

Hidayat, T. (2020). Pentingnya Peran Guru dan Orang Tua Saat Pembelajaran Jarak Jauh. https://www.kompasiana.com/taufikdayat26/5f34b636d541df7629701825/pentingnya-peranguru-dan-orang-tua-saat-pembelajaran-jarak-jauh

Irawati, R., \& Santaria, R. (2020). Persepsi Siswa SMAN 1 Palopo Terhadap Pelaksanaan Pembelajaran Daring Mata Pelajaran Kimia Jurnal Studi Guru Dan Pembelajaran. 3(2), 264-270.

Jena, P. K. (2020). Online learning during lockdown period for covid-19 in india. International Journal of Multidisciplinary Educational Research, 9 (5 (8)), 82-92.

Kawuryan, M. N. (2016). “Pengembangan Pendidikan Karakter Bangsa Berbasis Kearifan Lokal dalam Era MEA " Pengembangan Model Peran Orang Tua , Guru, dan Masyarakat dalam Proses Pembelajaran untuk Membentuk Intensi Berperilaku Anak Peduli Lingkungan SEMINAR NASIONAL PENDIDIKAN 2. 1.

Kurnianto, B., \& Rahmawati, R. D. (2020). Hubungan Pola Asuh Orang Tua terhadap Motivasi Belajar Siswa Pada Pembelajaran Daring Masa Pandemi. Sendika, 2, 1-11.

Kurniati, E., Nur Alfaeni, D. K., \& Andriani, F. (2020). Analisis Peran Orang Tua dalam Mendampingi Anak di Masa Pandemi Covid-19. Jurnal Obsesi: Jurnal Pendidikan Anak Usia Dini, 5(1), 241. https://doi.org/10.31004/obsesi.v5i1.541

Morgan, H. (2020). Best Practices for Implementing Remote Learning during a Pandemic. The Clearing House: A Journal of Educational Strategies, Issues and Ideas, 93(3), 135-141. https://doi.org/10.1080/00098655.2020.1751480

Musmirotun, K. (2021). Peran Orang Tua dalam Pembelajaran Daring Anak Usia Dini Kelompok B Di Ra Diponegoro 1 Kutawis Kecamatan Bukateja Kabupaten Purbalingga (Doctoral dissertation, IAIN Purwokerto).

Novianti, R., \& Garzia, M. (2020). Parental Engagement in Children's Online Learning During COVID-19 Pandemic. Journal of Teaching and Learning in Elementary Education (Jtlee), 3(2), 117. https://doi.org/10.33578/jtlee.v3i2.7845

Reimers, F., Schleicher, A., Saavedra, J., \& Tuominen, S. (2020). Supporting the continuation of teaching and learning during the COVID-19 Pandemic. Oecd, 1(1), 1-38.

Ruli, E. (2020). Tugas dan peran orang tua dalam mendidk anak. Jurnal Edukasi Nonformal, 1(2), 143-146. https://ummaspul.e-journal.id/JENFOL/article/view/428

Sapardan, D. A. (2020). Peran Orang Tua Dalam Pembelajaran Jarak Jauh. https://disdikkbb.org/news/peranorang-tua-dalam-pembelajaran-jarak-jauh/

Saragih, A., \& Hasugian, J. W. (2020). Model Asuhan Keluarga Kristen di Masa Pandemi Covid-19. Jurnal Teruna Bhakti, 3(1), 1. https://doi.org/10.47131/jtb.v3i1.56

Sari, W., Rifki, A. M., \& Karmila, M. (2020). Pembelajaran Jarak Jauh Pada Masa Darurat Covid 19. Jurnal MAPPESONA, 1, 12.

Syamsiah, P. N., Rahmawati, A., Atika, A., Wati, I. N., Yuliana, Y., \& Amirudin, M. F. (2021). Optimalisasi Peran Orang Tua Dalam Pembelajaran Daring Pada Masa Pandemi Covid-19 di Kelurahan Sumber Harta. Edification Journal: Pendidikan Agama Islam, 3(2), 153-174. 
Jurnal Ekonomi, Bisnis dan Pendidikan, 1(3), 2021, 240-250

WHO. (2021). Coronavirus Disease (COVID-19) Pandemic. https://www.who.int/emergencies/diseases/novelcoronavirus-2019?gclid=CjwKCAjwr_uCBhAFEiwAX8YJgSzZteagsjXsQzFN4ar-fjarAXfvINmn_A00c1izgepwV34BkdcRhoC-gAQAvD_BwE

Wijayanti, R. M., \& Fauziah, P. Y. (2020). Perspektif dan Peran Orangtua dalam Program PJJ Masa Pandemi Covid-19 di PAUD. Jurnal Obsesi: Jurnal Pendidikan Anak Usia Dini, 5(2), 1304-1312. https://doi.org/10.31004/obsesi.v5i2.768

Winingsih, E. (2020). Peran Orang Tua Dalam Pembelajaran Jarak Jauh. https://poskita.co/2020/04/02/peran-orangtuadalampembelajaran-jarak-jauh/

Yulianingsih, W., Suhanadji, S., Nugroho, R., \& Mustakim, M. (2020). Keterlibatan Orangtua dalam Pendampingan Belajar Anak selama Masa Pandemi Covid-19. Jurnal Obsesi : Jurnal Pendidikan Anak Usia Dini, 5(2), 1138-1150. https://doi.org/10.31004/obsesi.v5i2.740

Zahrok, S., \& Suarmini, N. W. (2018). Peran Perempuan Dalam Keluarga. IPTEK Journal of Proceedings Series, $O(5), 61$. https://doi.org/10.12962/j23546026.y2018i5.4422

Zhu, X., \& Liu, J. (2020). Education in and After Covid-19: Immediate Responses and Long-Term Visions. 2, 695699. https://doi.org/https://doi.org/10.1007/s42438-020-00126-3 